\title{
EVALUATION OF FRUIT QUALITY OF APPLE LAND VARIETIES
}

\author{
Ildikó Király ${ }^{1^{*}}$, Gyula Kovács², Katalin Molnár ${ }^{3}$, Wojciech J. Florkowskit \\ ${ }^{1}$ Department of Horticulture, Faculty of Horticulture and Rural Development, John von Neumann University \\ 2 Pórszombat, Hungary \\ ${ }^{3}$ Department of Horticulture, Faculty of Technical and Human Sciences, Târgu Mureş, Sapientia, Hungarian \\ University of Transylvania \\ ${ }^{4}$ Department of Agricultural and Applied Economics, University of Georgia, USA \\ https://doi.org/10.47833/2020.3.AGR.007
}

\section{Keywords:}

old apple varieties

Malus $\times$ domestica

fruit quality

functional food

\section{History:}

Received

Revised

Accepted
20 Nov 2020

25 Nov 2020

30 Nov 2020

\begin{abstract}
The study examines apple fruit quality attributes of eight cultivars, i.e., weight, size, flesh firmness, and soluble dry matter content. Half of the examined cultivars matched the fruit quality of the control 'Golden Delicious'. Additionally, the study evaluated each cultivar's nutritional value and how they can serve as functional foods.
\end{abstract}

\section{Introduction}

Numerous apple cultivars are planted globally, but only about ten cultivars are involved in intensive farming and apple producing countries vary somewhat in their cultivar choice. Old Hungarian apple varieties as well as the land varieties cannot compete in intensive farming, but they can have an important role in local markets and be suitable for fresh consumption. Many of the land varieties have unique nutritional values and specific traits that enable them to survive [3]; [7].

Land varieties are typically varieties that can adapt to the climate of a particular region. People grow land varieties for self-supply and local markets. A special variety structure was established in Hungary in the 1800s. Hungary's regional features strongly influenced development of their land varieties. Their exact origins are unknown. Today, they are known as typical varieties of a region [1]; [5]; [15].

Surányi [14] evaluates the benefits and drawbacks of old apple varieties and their scientific, economic, and socio-cultural effects in his book 'Gyümölcsöző sokféleség'. Surányi [14] states that the use of historic and land varieties contribute to biodiversity and successful nature conservation, provides healthy food, and improves the livelihoods of people in less developed regions.

A handful of publications focused on old apple varieties. Several authors reported results of studies carried out on gene bank collections [2]; [6]; [11]; [13]. Another set of studies examined the traditional apple varieties planted in orchards [8]; [10]; [15]; [16]; [17]; [18].

We examined apple land varieties that are excellent functional foods thanks to their role in folk medicine. The varieties originate from western Hungary. This study aims to find out whether the fruit quality of land varieties from traditional orchards can meet the quality of the control variety from a modern commercial orchard. The study examined fruit size, firmness, and soluble solids content. An attempt was made to prove the functional properties of the land varieties using laboratory tests.

\footnotetext{
* Contact person Tel.: +36 76,517,696

Email: kiraly.ildiko@kvk.uni-neumann.hu
} 


\section{Material and methods}

\subsection{Examined varieties}

We examined apple land varieties that are perceived as excellent functional foods in folk medicine. The fruit quality tests compare eight apple land varieties, i.e., 'Jóalma', 'Rétesalma', 'Bordás alma', 'Pirosló bőralma', 'Nyári édesalma', 'Piros pogácsa alma', 'Vasalma' and 'Kapitány alma' (Figure 1.) with frequently cultivated 'Golden Delicious' variety. Two samples of 'Golden Delicious' used in the test were from the gene bank of Pórszombat that applies traditional farming practices to fruits purchased at the market, likely originating from an orchard managed by intensive farming techniques. The samples of the examined eight apple land varieties from Gyula Kovács' gene bank in Pórszombat were from apple trees grafted on rootstock according to traditional practices. The examined apple land varieties are not listed in the National List of Varieties. Many of them can be considered classic land varieties from the Göcsej area, and have medicinal properties according to folk medicine. For example, 'Jóalma' should be eaten by women who just gave birth to reduce infant colic. 'Piros pogácsa alma' can be consumed by people with diabetes. There is no information on the healing effects of the other varieties but they are long-cultivated varieties in this area. The description of each apple land variety can be found on Gyula Kovács' website "Tündérkert" [9].
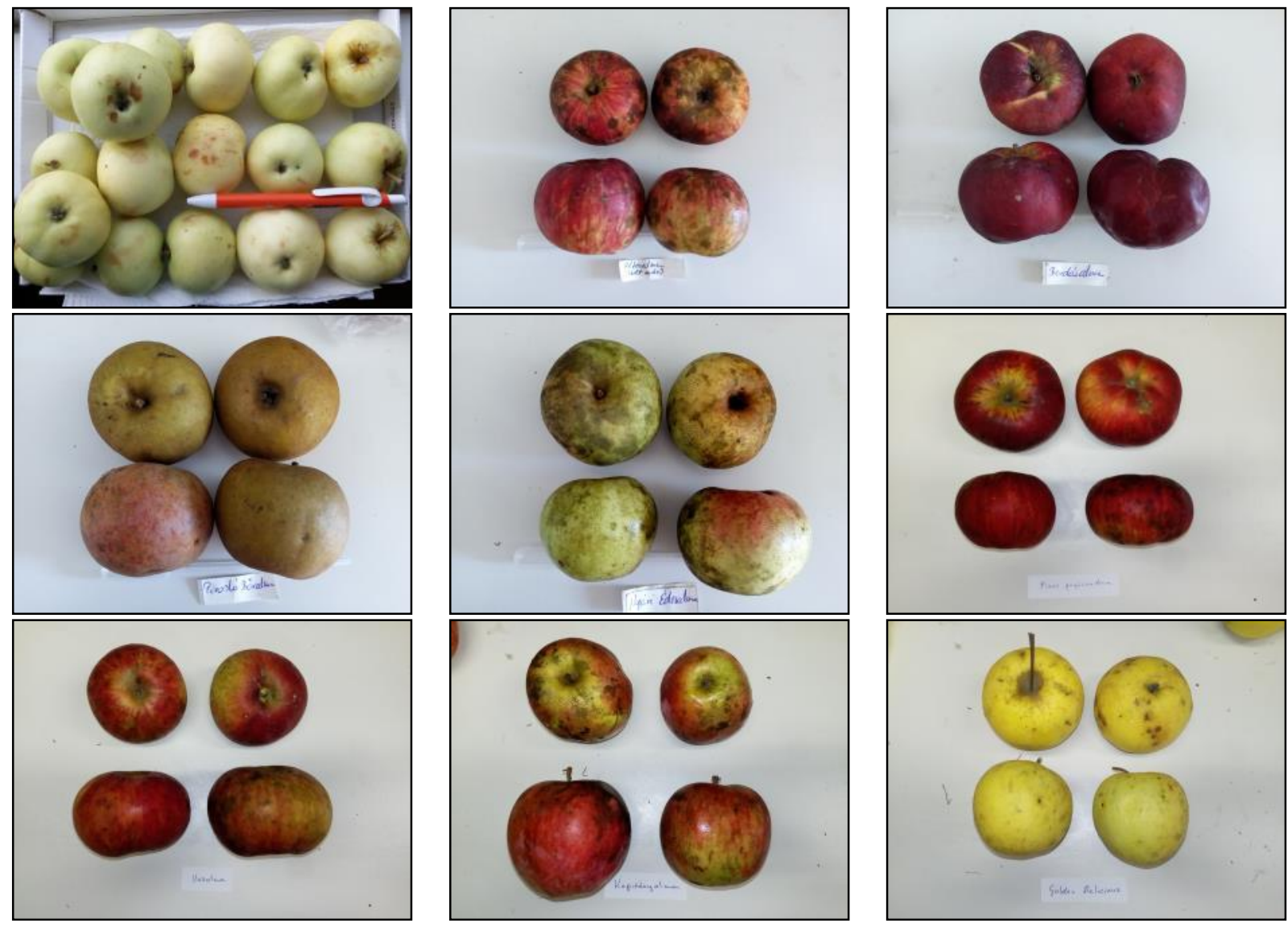

Figure 1. Examined apple fruit by cultivar (from left to right and from top to bottom): 'Jóalma", 'Rétesalma', 'Bordás alma', 'Pirosló bőralma', 'Nyári édesalma', 'Piros pogácsa alma', 'Vasalma', 'Kapitány alma', and 'Golden Delicious'. 


\subsection{Examined fruit parameters}

The laboratory tests were carried out in the Department of Horticulture and Rural Development, John von Neumann University in 2019. Only samples of 'Rétesalma' were collected twice (August 21 and September 16) because of damage caused by frost and wasps. The 'Rétesalma' fruits achieved their consumption maturity when the second sample was collected. The tests involved examination of the physical and chemical parameters of fruits and included height, diameter, weight, flesh firmness, and water-soluble dry matter content. The fruits were harvested when ready for consumption (Table 1.), and tested one or two days after the harvest. We collected 10-20 fruits per variety.

Table 1. Results of measurements of apple fruits of eight land varieties and a control

\begin{tabular}{|c|c|c|c|c|c|}
\hline Apple variety name & Functional properties ${ }^{[9]}$ & $\begin{array}{l}\text { Harvest } \\
\text { date in } \\
2019\end{array}$ & $\begin{array}{l}\text { Weight } \\
\text { (g) }\end{array}$ & $\begin{array}{c}\text { Firmness } \\
\left(\mathrm{kg} / \mathrm{cm}^{2}\right)\end{array}$ & Brix (\%) \\
\hline \multicolumn{6}{|l|}{ Early maturing } \\
\hline Jóalma & fresh consumption & 16 July & 71.22 & 5.94 & 11.30 \\
\hline \multicolumn{6}{|l|}{ Mid-season } \\
\hline Rétesalma & $\begin{array}{l}\text { fresh consumption, } \\
\text { cooking, store for short } \\
\text { time ( } 2-3 \text { weeks), dried } \\
\text { fruit, brandy }\end{array}$ & $\begin{array}{l}16 \\
\text { September }\end{array}$ & 103.57 & 4.60 & 14.30 \\
\hline Bordás alma & $\begin{array}{l}\text { fresh consumption, } \\
\text { cooking, juice, cider, cider } \\
\text { vinegar }\end{array}$ & $\begin{array}{l}16 \\
\text { September }\end{array}$ & 139.71 & 4.10 & 13.64 \\
\hline Pirosló bőralma & $\begin{array}{l}\text { fresh consumption, dried } \\
\text { fruit }\end{array}$ & $\begin{array}{l}16 \\
\text { September }\end{array}$ & 125.13 & 7.90 & 16.81 \\
\hline Nyári édesalma & $\begin{array}{l}\text { fresh consumption, store } \\
\text { for medium length time (2- } \\
3 \text { months), cider, cider } \\
\text { vinegar, brandy, dried } \\
\text { fruit, feeding }\end{array}$ & $\begin{array}{l}16 \\
\text { September }\end{array}$ & 92.45 & 8.60 & 15.45 \\
\hline \multicolumn{6}{|l|}{ Late maturing } \\
\hline Piros pogácsa alma & $\begin{array}{l}\text { fresh consumption, store } \\
\text { for longest time ( } 4-5 \\
\text { months), cider, cider } \\
\text { vinegar, brandy, feeding }\end{array}$ & $\begin{array}{l}4 \\
\text { November }\end{array}$ & 172.83 & 3.80 & 13.63 \\
\hline Vasalma & $\begin{array}{l}\text { cooking, store for longest } \\
\text { time ( } 4-5 \text { months), cider } \\
\text { vinegar, brandy, feeding }\end{array}$ & $\begin{array}{l}4 \\
\text { November }\end{array}$ & 179.50 & 8.34 & 16.75 \\
\hline Kapitány alma & $\begin{array}{l}\text { fresh consumption, store } \\
\text { for longest time ( } 4-5 \\
\text { months), cider vinegar, } \\
\text { brandy, preserved fruit }\end{array}$ & $\begin{array}{l}4 \\
\text { November }\end{array}$ & 105.14 & 3.50 & 12.50 \\
\hline \multicolumn{6}{|l|}{ Control } \\
\hline $\begin{array}{l}\text { Golden Delicious } \\
\text { (Pórszombat) }\end{array}$ & & $\begin{array}{l}4 \\
\text { November }\end{array}$ & 100.25 & 3.69 & 9.25 \\
\hline Golden Delicious & & $\begin{array}{l}8 \\
\text { November* }\end{array}$ & 178.83 & 4.53 & 12.25 \\
\hline
\end{tabular}


The height and diameter of each apple were measured with a caliper. The weight of each fruit was measured with the use of a gram kitchen scale. After removing the peel, we measured the flesh firmness of the fruits with the help of a manual penetrometer with an $11 \mathrm{~mm}$ diameter. Several measurements were made on the shady and sunny side of each fruit. This was done because of the limited number of samples. A manual refractometer was used to measure the water-soluble dry matter content. To establish the water-soluble dry matter content, we collected samples with an increment borer from four to six places on each fruit.

\section{Results}

\subsection{Apple fruit physical parameters}

The fruit of the variety control 'Golden Delicious' has both a height and diameter of $70 \mathrm{~mm}$. Its configuration index is 0.92 (Figure 2.). The 'Golden Delicious' sample from traditional orchard had a similar fruit size of $80 \mathrm{~mm}$, probably resulting from the intensive growing practices. The fruit size of the land varieties ranges from small to medium-large. 'Kapitány alma' had a similar configuration index (0.94) to 'Golden Delicious'. 'Vasalma' and 'Piros pogácsa alma' had bigger width than the control. Their configuration indexes are 0.75 and 0.65 , respectively, implying a flattened fruit shape. Except for 'Piros pogácsa alma' and 'Kapitányalma', the other land varieties had a slightly flattened, roundish shape with a configuration index of 0.8 .

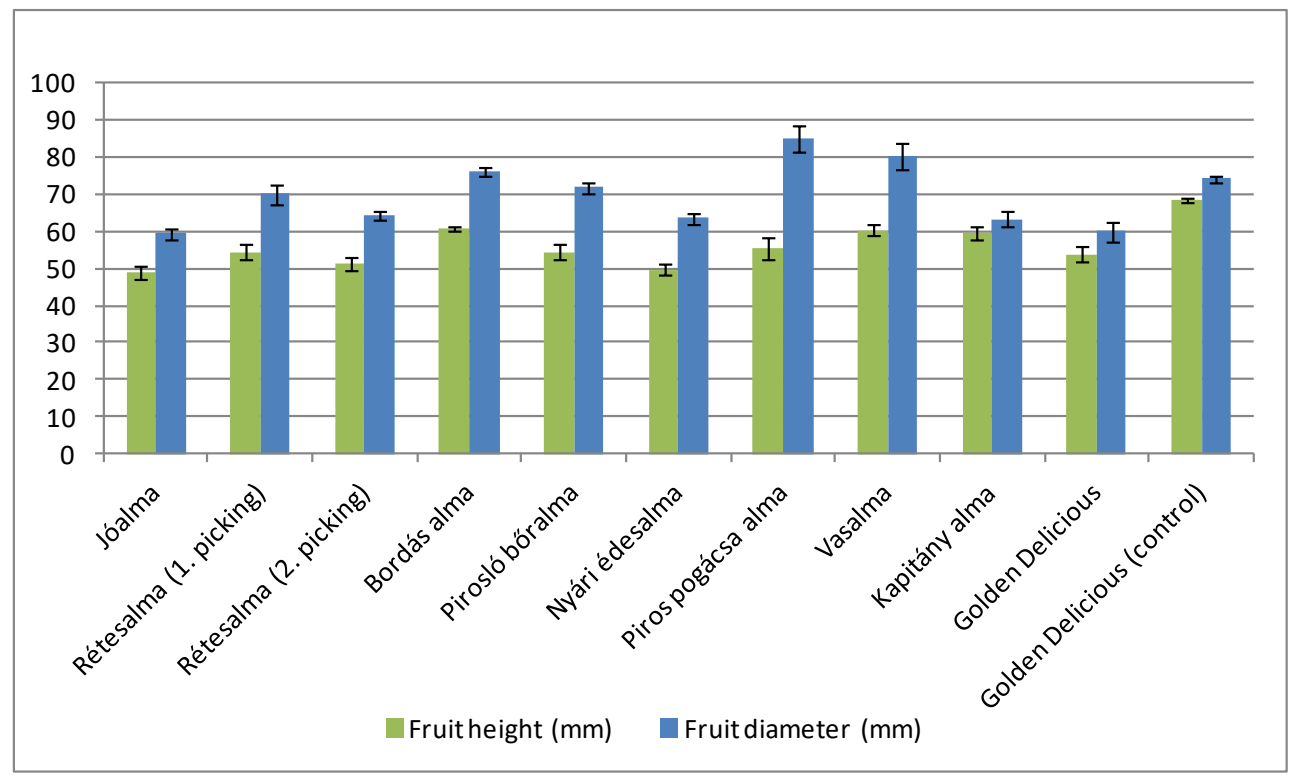

Figure 2. Height and diameter of apple land varieties and a control (Pórszombat, 2019)

The control apple variety, 'Golden Delicious', had an average fruit weight of $180 \mathrm{~g}$. 'Vasalma' and 'Piros pogácsa alma' also had similar average weights per fruit (Figure 3.) 'Golden Delicious' from a traditional orchard had a lighter fruit weight (100 $\mathrm{g}$ on average) due to intensive growing practices. The remaining land varieties had small to medium-large average fruit weights of $70 \mathrm{~g}$ to $140 \mathrm{~g}$. 


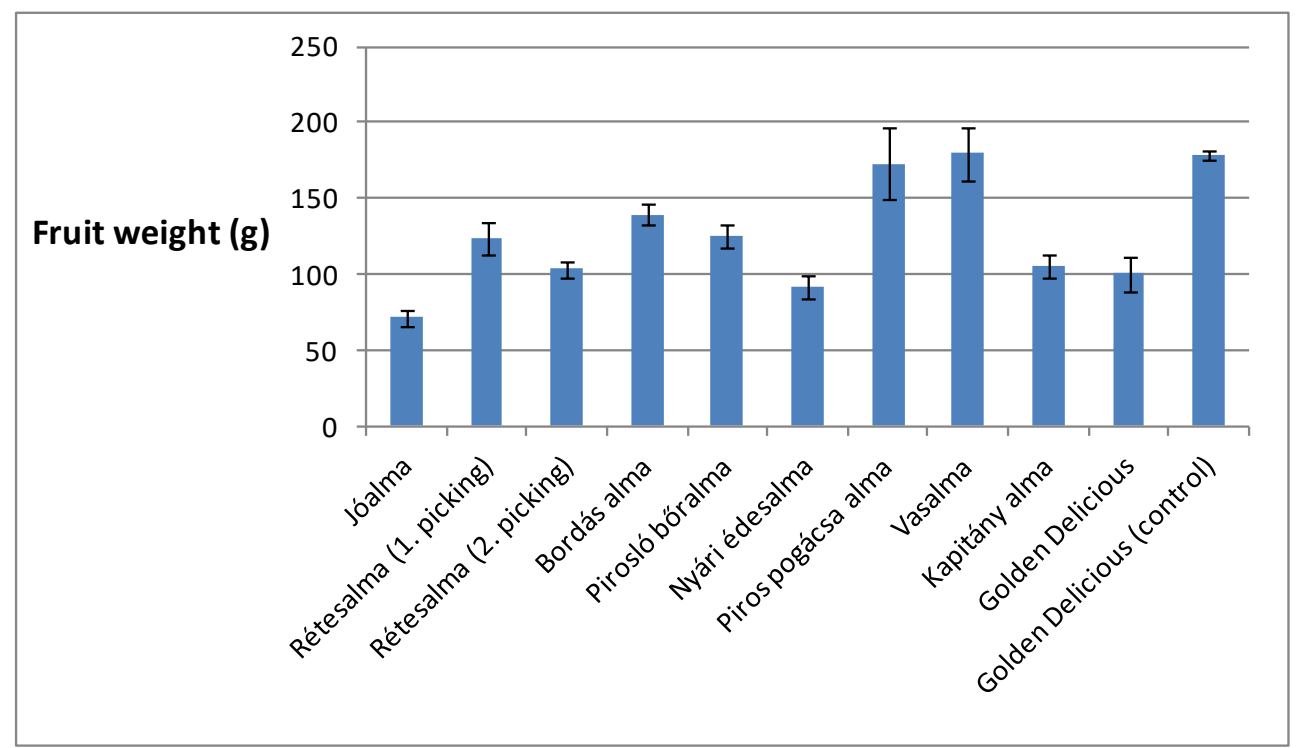

Figure 3. Average fruit weight of apple land varieties and a control (Pórszombat, 2019)

Flesh firmness measurements in apple fruits of five land varieties, 'Jóalma', 'Rétesalma' (first harvest), 'Pirosló bőralma', 'Nyári édesalma', and 'Vasalma', was measured in a larger number of places than in the control variety 'Golden Delicious'. The other land varieties were found to have firmness $(4 \mathrm{~kg} / \mathrm{cm} 2)$ similar to that of the control sample (Figure 4). Differences between the two samples of 'Golden Delicious' emerge because of their different storage circumstances (coldstorage vs. standard refrigerator). Before the testing began, apple fruit samples collected in Pórszombat were stored in a standard refrigerator (approx in $8^{\circ} \mathrm{C}$ ). Refrigeration slows ripening less effectively than cold-storage since a temperature range of two centigrade to four centigrade cannot be assured in a standard refrigerator.

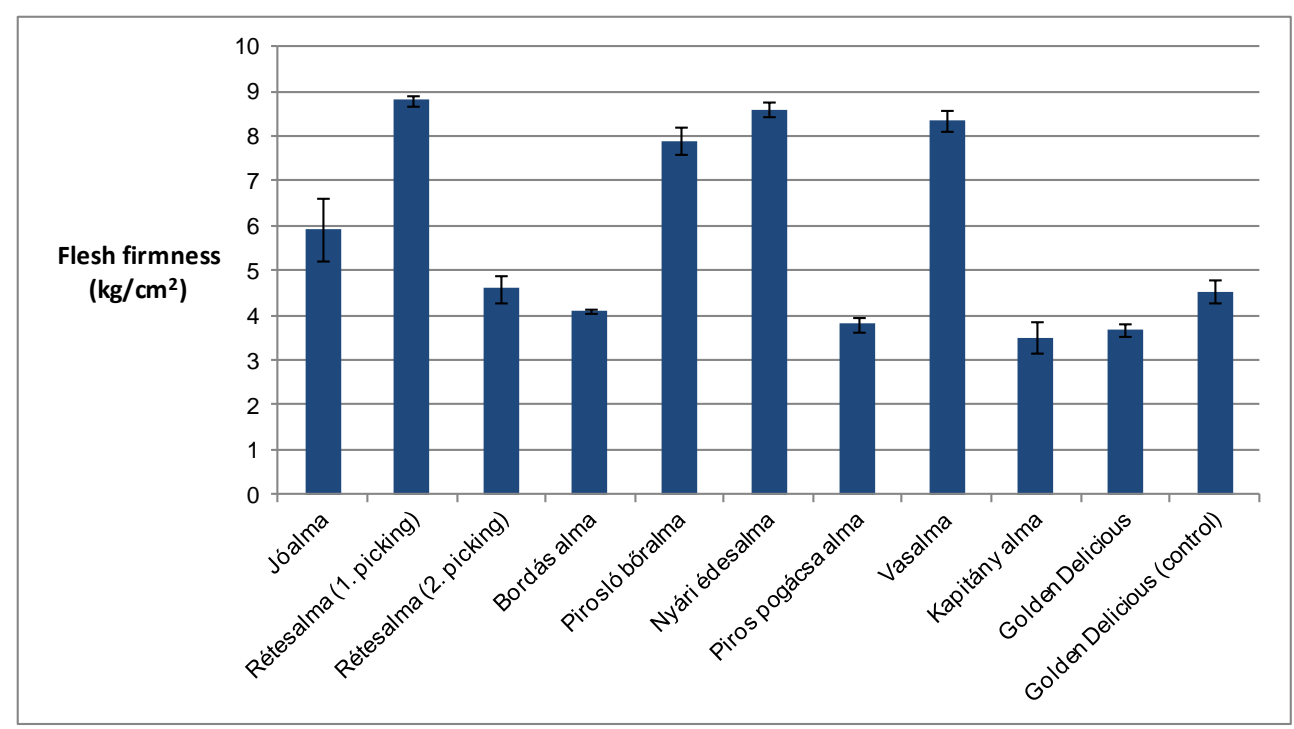

Figure 4. Apple fruit firmness by cultivar (Pórszombat, 2019) 


\subsection{Water-soluble dry matter content (Brix value)}

The water-soluble dry matter content of the land varieties ranged from 11 to 17 Brix value and equaled or exceeded Brix of the control 'Golden Delicious' (Figure 5.). The sample of 'Golden Delicious' from a conventional orchard in Pórszombat had a lower Brix value than the sample from a high density orchard which had reached Brix 12. An earlier study [6] also reported a Brix value of 12 in the case of 'Golden Delicious'. Varieties with Brix values higher than 12 are suitable for making apple juice concentrate [12]. Excepting 'Jóalma', the examined land varieties were suitable for processing if their acidity was around $7 \mathrm{~g} / \mathrm{l}$. Earlier studies in Hungary confirmed a medium-high (at least Brix value 12) content of water-soluble dry matter from most of the old Hungarian apple varieties [2]; [8]; [11]; [13]; [17].

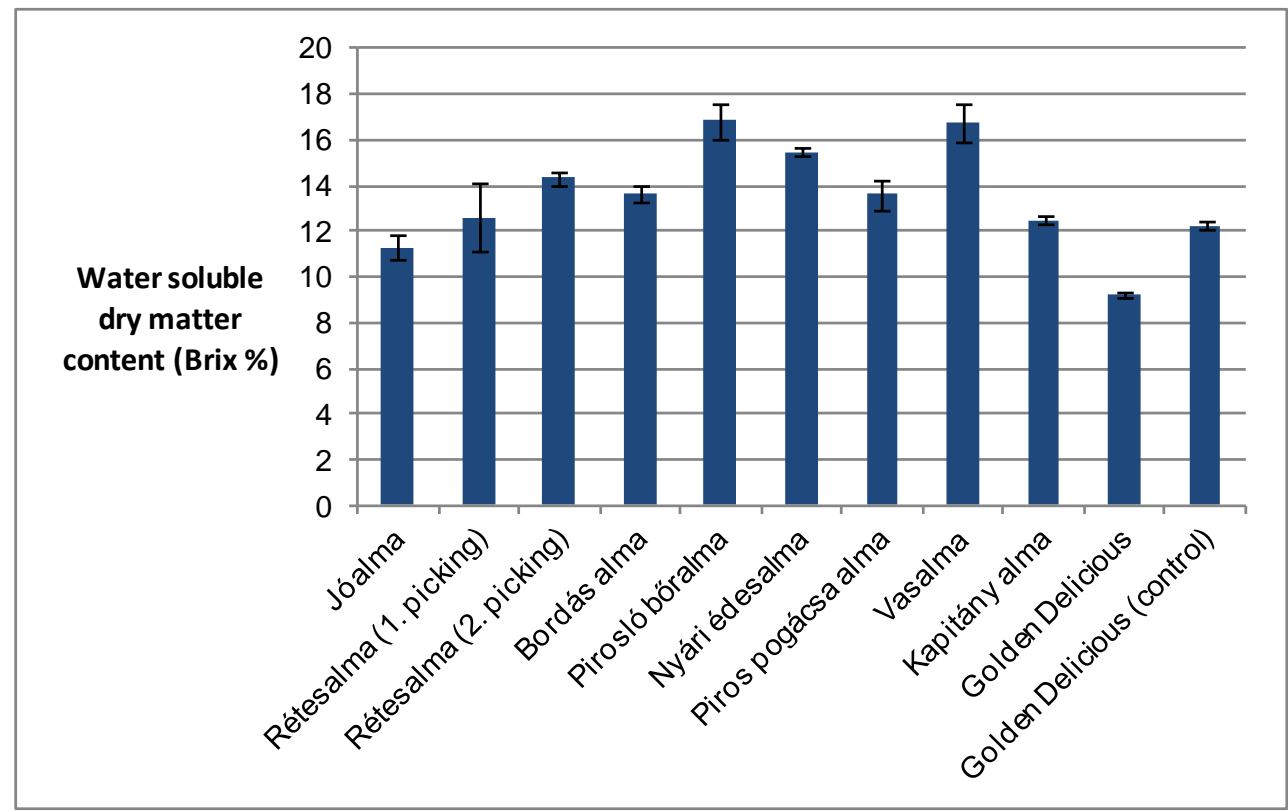

Figure 5. Water-soluble dry matter content of apple fruit of eight land varieties and a control

(Pórszombat, 2019)

\section{Conclusions}

The fruit size of apple land varieties from conventional orchards equalled or was smaller than the control variety sample from intensive farming. In most cases flesh firmness and water-soluble dry matter content of the land varieties were higher than the control. As the land varieties can compete in the market thanks to their physical parameters and sugar content, they are worth further testing. In our further examinations we will try to prove the health care values of the land varieties by laboratory tests (sugar and acidic composition, antioxidant and polyphenol content, mineral element content).

\section{Acknowledgement}

The authors acknowledge financial support provided under the framework of the EFOP3.6.2-16-2017-00012 "Developing functional, healthy and safe food product chain model from field to table in a thematic research network". The project was funded by the Government of Hungary and the European Union, co-financed by the European Social Fund, and is part of the Széchenyi 2020 program. 


\section{References}

[1] Csambalik L.,Divéky-Ertsey A. (2016): A tájfajta kifejezés definíciói és szinonimái. KERTGAZDASÁG. 48(4): 313.

[2] Ficzek G., Nagyistván O., Király I., Papp D., Tóth M. (2017): Fruit quality of old apple cultivars of the Carpathian Basin. Acta Horticulturae: Technical Communications of ISHS 1172: pp. 339-344. DOI: 10.17660/ActaHortic.2017.1172.63

[3] G. Tóth M. (2005a): A Kárpát-medence régi almafajtáinak felderítése és megmentése. Kertgazdaság, 37(2):2429.

[4] G. Tóth M. (2005b): Régi magyar almafajták mint a rezisztencianemesítés génforrásai és a környezettudatos külterjes gyümölcsök elemei. Kertgazdaság special issue. A fajtaválaszték fejlesztése a kertészetben, 23-31. p.

[5] Holler C. (2007): Régi gyümölcsfajták és hagyományos gyümölcsök: A táj, a természet, és az ember kincsei. Kertgazdaság, 39(3):76-80.

[6] Király I., Ficzek G., Tóth M. (2019): Ökológiai termesztésre javasolt régi magyar almafajták beltartalmi értékeinek vizsgálata. In: Kőszegi, Irén Rita (ed.) III. Gazdálkodás és Menedzsment Tudományos Konferencia : Versenyképesség és innováció Kecskemét, Magyarország. 592-598.

[7] Király I., Szabó T., Budainé Veres Á., Tabakovic, A., Tóth M. (2015): Régi magyar almafajták ökológiai termesztésre való alkalmasságának értékelése. Gradus 2:(2) pp. 275-282.

[8] Komonyi É. (2010): Kárpátalja tájalmafajtáinak pomológiai leírása. Acta Beregsasiensis, IX(1):245-254.

[9] Gyula Kovács (2020): Tündérkertek. www.tündérkertek.hu. Acquired: 01. 06. 2020.

[10] Nagy-Tóth F. (1998): Régi erdélyi almák. Kolozsvár: Erdélyi Múzeum-Egyesület, 352. p.

[11] Papp D., Ficzek G., Stégerné Máté M., Nótin B., Király I., Tóth M. (2011): Kárpát-medencei régi almafajták beltartalmi értékei és perspektívái a XXI. század hazai gyümölcsnemesítésében. Kertgazdaság, 43(1):23-27.

[12] Papp J. (ed.). (2004): A gyümölcsök termesztése. Mezőgazda Kiadó. Budapest.

[13] Racskó J., Szabó T., Soltész M., Szabó Z., Nyéki J. (2005): Régi magyar alma tájfajták gyümölcsmorfológiai és beltartalmi sajátosságai. Kertgazdaság, 37(3):23-35.

[14] Surányi D. 2002. Gyümölcsöző sokféleség: Biodiverzitás a gyümölcstermesztésben. Cegléd: Akcident Nyomdaipari Kft. 140. p.

[15] Szani Zs. (2007): Alma tájfajták táji tagozódása Magyarországon. Kertgazdaság, 39(2):21-26.

[16] Szani Zs. (2011): Történelmi alma- és körtefajták a Kárpát-medencében a népi fajtaismeret és -használat tükrében. PhD thesis. Budapest

[17] Tóth M., Balikó E., Szani Zs. (2005): Evaluation of fruit quality of old apple cultivars originating from the foot of the Carpathian Mountains, for utilization in breeding and in organic farming. Int J Hortic Sci, 11(3):15-21. DOI: https://doi.org/10.31421//JHS/11/3/593

[18] Tóth M., Szani Zs. (2004): Traditional farming within the Carpathian basin - pomaceous fruits. Int J Hortic Sci, 10(3):15-18. DOI: https://doi.org/10.31421//JHS/10/3/497 